Удк о04.91:614.2:616.831-005.1

\title{
ІНДИВІДУАЛЬНА ЕЛЕКТРОННА КАРТА ПАЦІЄНТА ДЛЯ ПОСТІНСУЛЬТНИХ ХВОРИХ
}

\author{
О. Ю. Азархов ${ }^{1}$, С. М. Злепко ${ }^{2}$, О. В. Бєлоусова ${ }^{2}$ \\ ПУ Санаторій «Металург»' \\ Вінницький національний технічний університет ${ }^{2}$
}

В роботі розроблена структура і зміст індивідуальної електронної медичної карти для людей, які перенесли мозковий інсульт. ії застосування істотно підвищує якість надання медичної допомоги.

Ключові слова: електронна медична карта, мозковий інсульт, реабілітація.

\section{ИНДИВИДУАЛЬНАЯ ЭЛЕКТРОННАЯ КАРТА ПАЦИЕНТА ДЛЯ ПОСТИНСУЛЬТНЫХ БОЛЬНЫХ}

\author{
А. Ю. Азархов ${ }^{1}$, С. М. Злепко ${ }^{2}$, О. В. Белоусова ${ }^{2}$ \\ 'ЧУ Санаторий «Металлург» \\ ${ }^{2}$ Винницкий национальный технический университет \\ В работе разработана структура и содержание индивидуальной электронной медицинской карты для людей, \\ которые перенесли мозговой инсульт. Ее использование существенно повышает качество предоставления меди- \\ цинской помощи. \\ Ключевые слова: электронная медицинская карта, мозговой инсульт, реабилитация. \\ INDIVIDUAL ELECTRONIC CARD FOR POST-APOPLECTIC PATIENTS \\ O. Yu. Azarkhov', S. M. Zlepko², O. V. Belousova ${ }^{2}$ \\ 'Private Sanatorium «Metalurh» \\ ${ }^{2}$ Vinnytsia National Technical University
}

\begin{abstract}
In the given article a structure and maintenance of individual electronic medical card is developed for people who underment a cerebral stroke. Its use substantially promotes quality of medical care.
\end{abstract}

Key words: electronic medical card, cerebral stroke, rehabilitation.

Вступ. Індивідуальна електронна медична карта, за визначенням Міжнародної організації зі стандартизації (ISO), - це сховище інформації про стан здоров'я людини у формі, яка може бути оброблена комп'ютером, безпечно зберігатися та передаватися, доступна для багатьох авторизованих користувачів. Вона містить стандартизовану або загальноприйняту модель логічної інформації (ретроспективні, поточні та прогностичні дані), що не залежить від системи карти. Її функція - підтримка послідовної, ефективної та інтегрованої медичної допомоги [1].

Існує декілька можливих варіантів і переваг широкого використання індивідуальної електронної карти (IEK). Вони сприяють зменшенню кількості лікарських помилок, підвищують ефективність роботи ліка- ря, зменшують витрати і сприяють стандартизації медичної допомоги [2].

Матеріал і методи. У роботі були використані результати клініко-експериментальних досліджень хворих із різними типами мозкового інсульту, які проходили лікування в клінічних і санаторних установах міст Вінниці і Маріуполя. Спостерігали 76 хворих з ішемічним інсультом (давність захворювання - 2-7 тижнів). Оцінку рівня неврологічного дефіциту і незалежності пацієнтів в повсякденному житті проводили з використанням Американської шкали ступеня тяжкості інсульту, індексу Бартела і шкали Ренкіна.

Результати та їх обговорення. На рисунку 1 представлено запропонований нами один із варіантів структурно-функціональної організації індивідуальної 


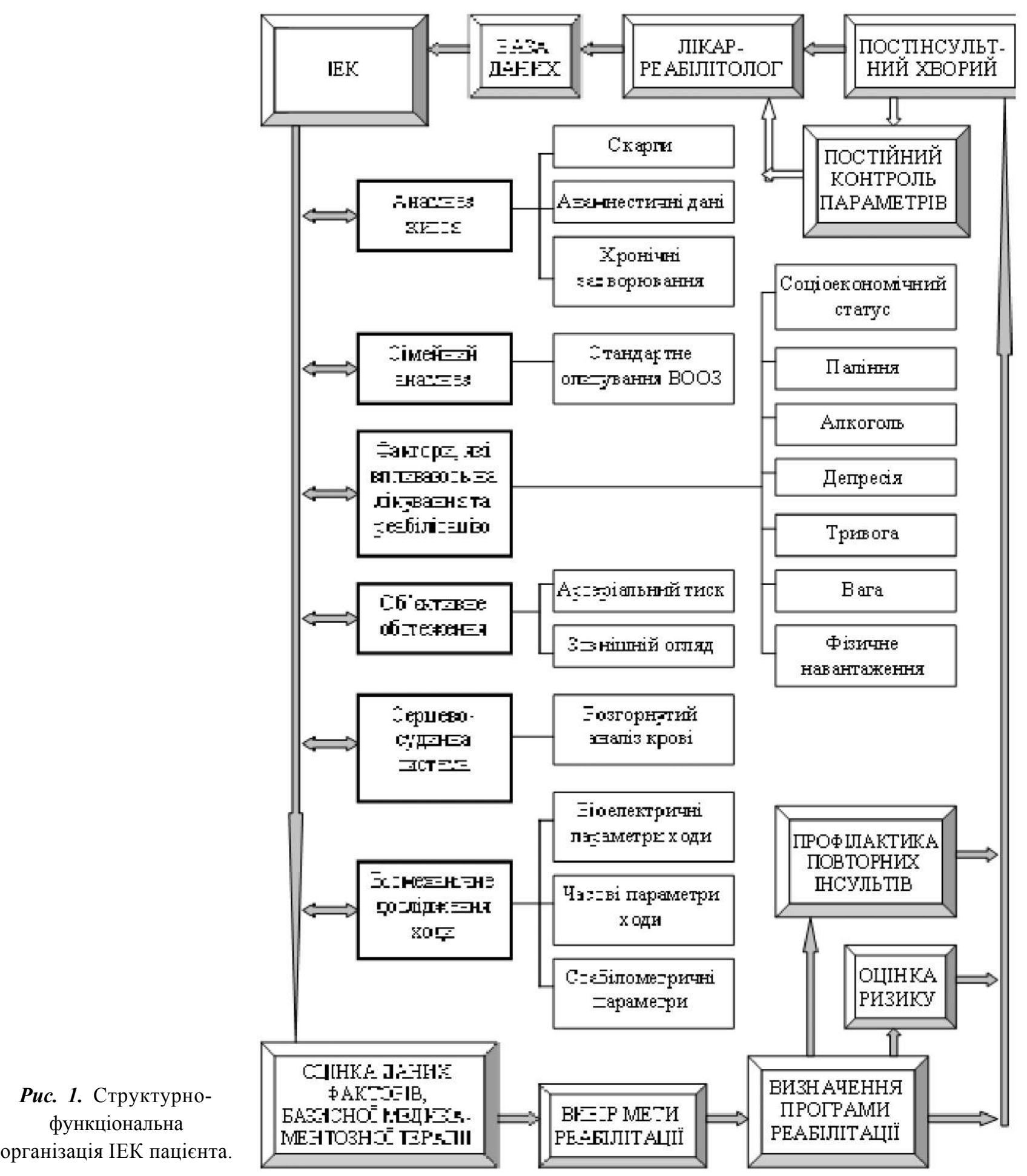

карти пацієнта, максимально орієнтованої на діагностику, дослідження, супровід і реабілітацію хворих, які перенесли мозковий інсульт.

Індивідуальна карта пацієнта, що включає визначену кількість ознак, з яких лікар визначає необхідні, дозволяє зафіксувати основні прояви захворювань, що мають значення для оцінки соціальної адаптованості пацієнта та його потреби у медико-психологопедагогічній корекції. Для більш точної реєстрації клінічних проявів різного роду патологій, де мають особливе значення специфічні відхилення і функціональні порушення, що впливають на ступінь інвалідності, є карти сателітів, необхідність використання яких визначається лікарем у кожному конкретному випадку, оскільки основні прояви цих порушень відображені в базовій карті.

Карта побудована за єдиною схемою у вигляді питань 3 альтернативними варіантами відповідей і тек- 
стових полів для внесення інформації про індивідуальні особливості прояву захворювання. Введення даних здійснюється лікарем в діалоговому режимі. Кодування ознак ведеться автоматично в процесі введення при виборі ознак на екрані дисплея з вбудованих класифікаторів, які включають не тільки діагнози і функціональні зміни, але і характер змін по органах і системах організму.

Медико-соціальний висновок щодо постінсультного пацієнта, дані для якого автоматично вибираються із заповненої карти і представляються лікареві для остаточного редагування, дозволяє отримати повне уявлення про уражені функції хворого, тяжкість функціональних обмежень, сумарний реабілітаційний потенціал, характер захворювання, план медико-соціальної реабілітації і раніше призначених заходів тощо.

У підсистемі передбачена інтеграція баз даних нижнього (поліклінічного - персоніфікованого) і вищих рівнів (районного, міського, обласного, міжобласного - статистичних), що забезпечує формування баз даних постінсультних хворих на всіх рівнях охорони здоров'я. Така концепція обліку і аналізу інвалідності є основою для моніторингу стану здоров'я і соціальної адаптації хворих, що перенесли інсульт, планування медичних і соціальних заходів, що усувають дезадаптацію [3].

Спеціальна база даних призначена для підтримки процесу ухвалення рішень про об'єм і терміни реабілітації хворих після перенесеного інсульту, для вдосконалення обліку даного контингенту, раціонального планування і контролю етапних лікувально-реабілітаційних заходів. Створення даної підсистеми обумовлене тим, що дезорганізація структури і функціонування територіальних систем охорони здоров'я i соціального захисту в умовах вимушеної і природної міграції населення порушує етапність в наданні медичної допомоги і реєстрації медичних даних. Інформація про попередні заходи стосовно хворих, які перенесли інсульт, особливо важлива для лікарів стаціонарів, куди вони поступають після надання первинної допомоги, а також для проведення подальшої корекції або реабілітації в спеціалізованих лікувально-діагностичних і профілактичних установах.

Оперативний доступ до цих даних можливий тільки при функціонуванні автоматизованих інформаційнопошукових систем. У цьому випадку, використовуючи сучасні телекомунікаційні канали, лікарі матимуть можливість перегляду необхідних їм даних про механізми травми і лікування хворого, які зберігаються в історіях хвороби за місцем попереднього лікування. Тому існує необхідність створення інформаційної підсистеми, яка б об'єднала дані про хворих, що перенесли інсульт, і потенційно потребують тривалого (повторного) лікування або реабілітації.

Електронний аналог індивідуальної карти пацієнта містить дані пацієнта, включаючи відомості про батьків, родичів, анамнез життя, діагнози, зведення про етапи лікування, інвалідність, потреби в реабілітаційних заходах. Інформаційна підсистема орієнтована на вирішення питань: зберігання даних про хворих, підтримки процесу ухвалення рішень про об'єм і терміни постінсультної реабілітації, обліку даного контингенту пацієнтів, раціонального планування і контролю етапних реабілітаційних медичних і соціальних заходів.

База даних системи містить: оцінку функціональних змін, патологічних порушень і характеру соціальної адаптованості, відомості про рівень і структуру порушених функцій на даний час, дані про реабілітацію хворих на різних етапах надання медичної і соціальної допомоги, оцінку обмежень життєдіяльності, оцінку потреби в протезуванні та допоміжних засобах.

Зміст індивідуальної електронної карти постінсультного хворого.

До даних картки належать загальні відомості: номер індивідуальної картки, прізвище, ім'я та по-батькові пацієнта, дата огляду, адреса та телефон, стать, вік та клінічний діагноз пацієнта.

Інші дані картки поділені на 8 розділів-опитувальників. Вміст цих розділів представлений в табл. 1 (розділи карти 1-7) і на рис. 2 (розділ 8).

Таблиця 1. Вміст індивідуальної електронної карти

\begin{tabular}{|l|l|}
\hline \multicolumn{1}{|c|}{ 1. Анамнез життя } & \\
\hline 1.Чи скаржилися Ви на головні болі (якщо так, відповісти на запитання 2, 3, 4, 5, 6) & \\
\hline 2. Коли вони вперше виникли? & \\
\hline 3. Після чого з'являються (фізичне навантаження, стрес)? & \\
\hline 4. Коли турбують (вдень, вночі)? & \\
\hline 5. Тривалість. & \\
\hline 6. Після чого зникають? & \\
\hline $\begin{array}{l}\text { 7. Який у Вас тиск? (нормальний, підвищений, знижений, не знаєте) Якщзо підвищений, } \\
\text { відповісти на питання 8, 9, 10 }\end{array}$ & \\
\hline 8. Коли вперше виявили? & \\
\hline
\end{tabular}


Продовження табл. 1

\section{1. Анамнез життя}

9.Чи спостерігалася зміна Вашого стану після цього (погіршення, поліпшення, не змінився, не знаєте)?

10. Чи знаходилися Ви на стаціонарному лікуванні з приводу артеріальної гіпертензії? Скільки разів?

11. Чи приймаєте Ви лікування 3 метою зниження артеріального тиску (якщо так, перерахувати препарати)?

12. Чи були у Вас гіпертонічні кризи?

13. Чи виявляєте Ви скарги на біль в ділянці серця?

14. Чи є скарги на серцебиття?

15. Наявність хронічних захворювань (цукровий діабет, подагра, хронічні обструктивні захворювання легень)

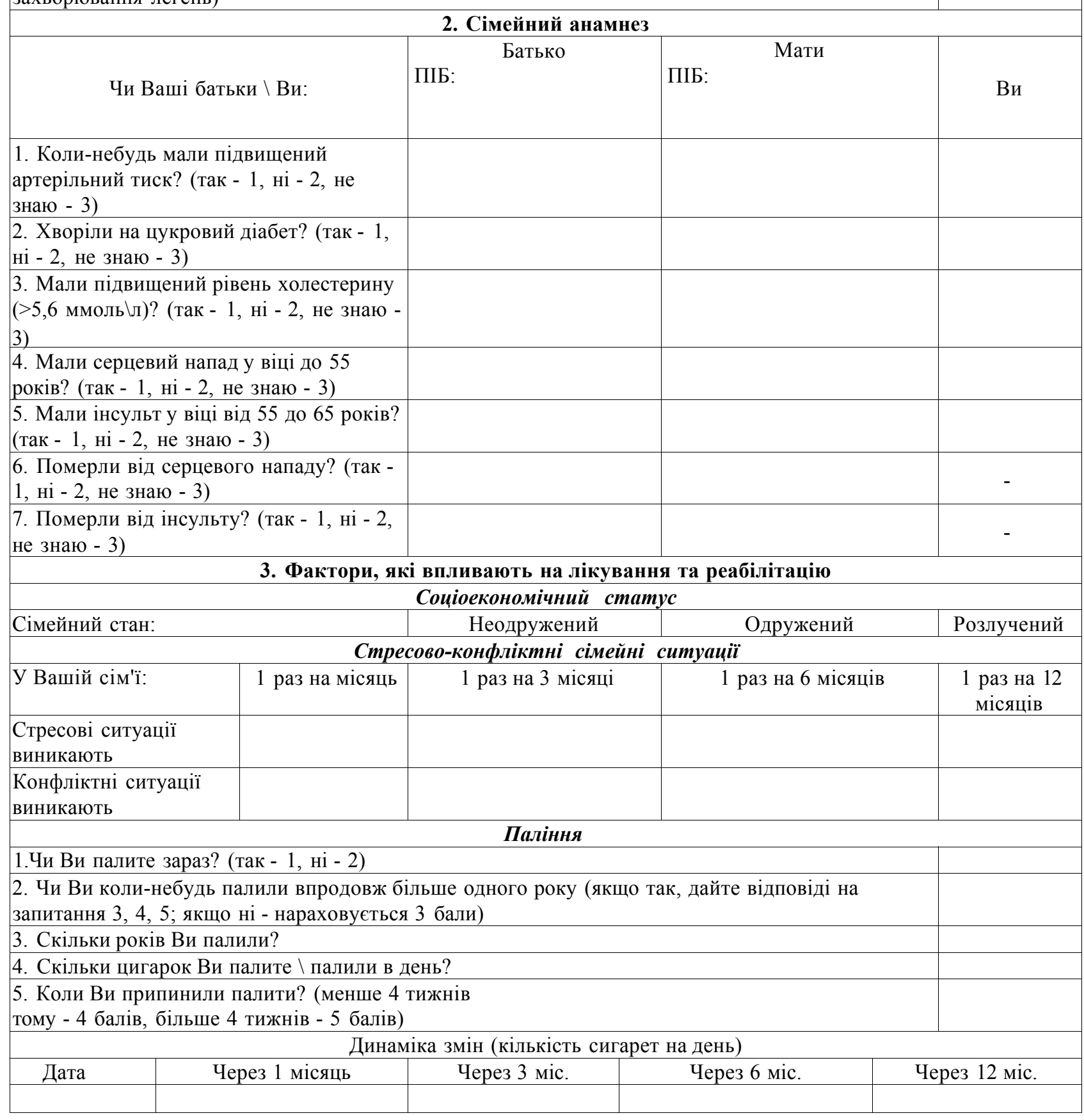


Продовження табл. 1

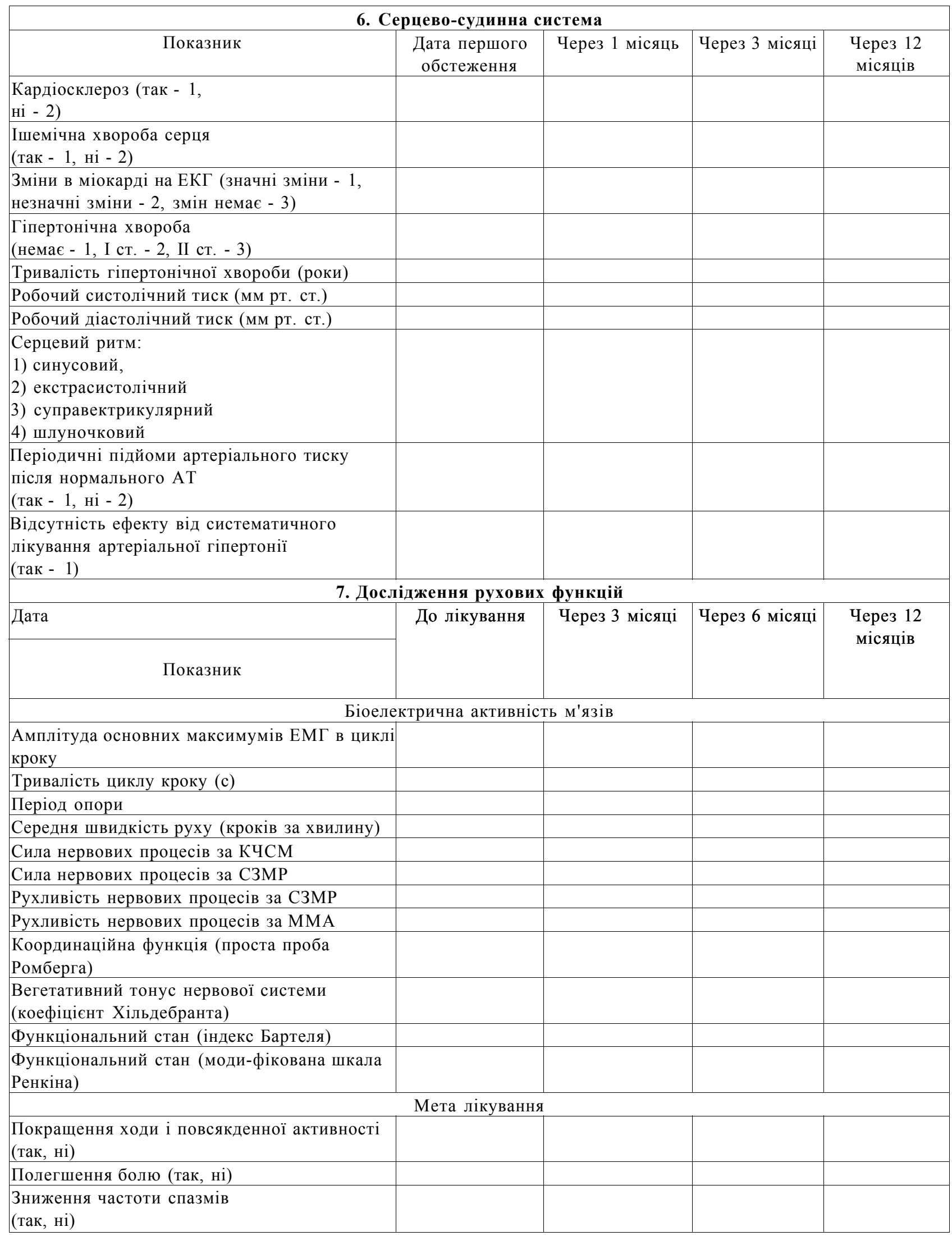




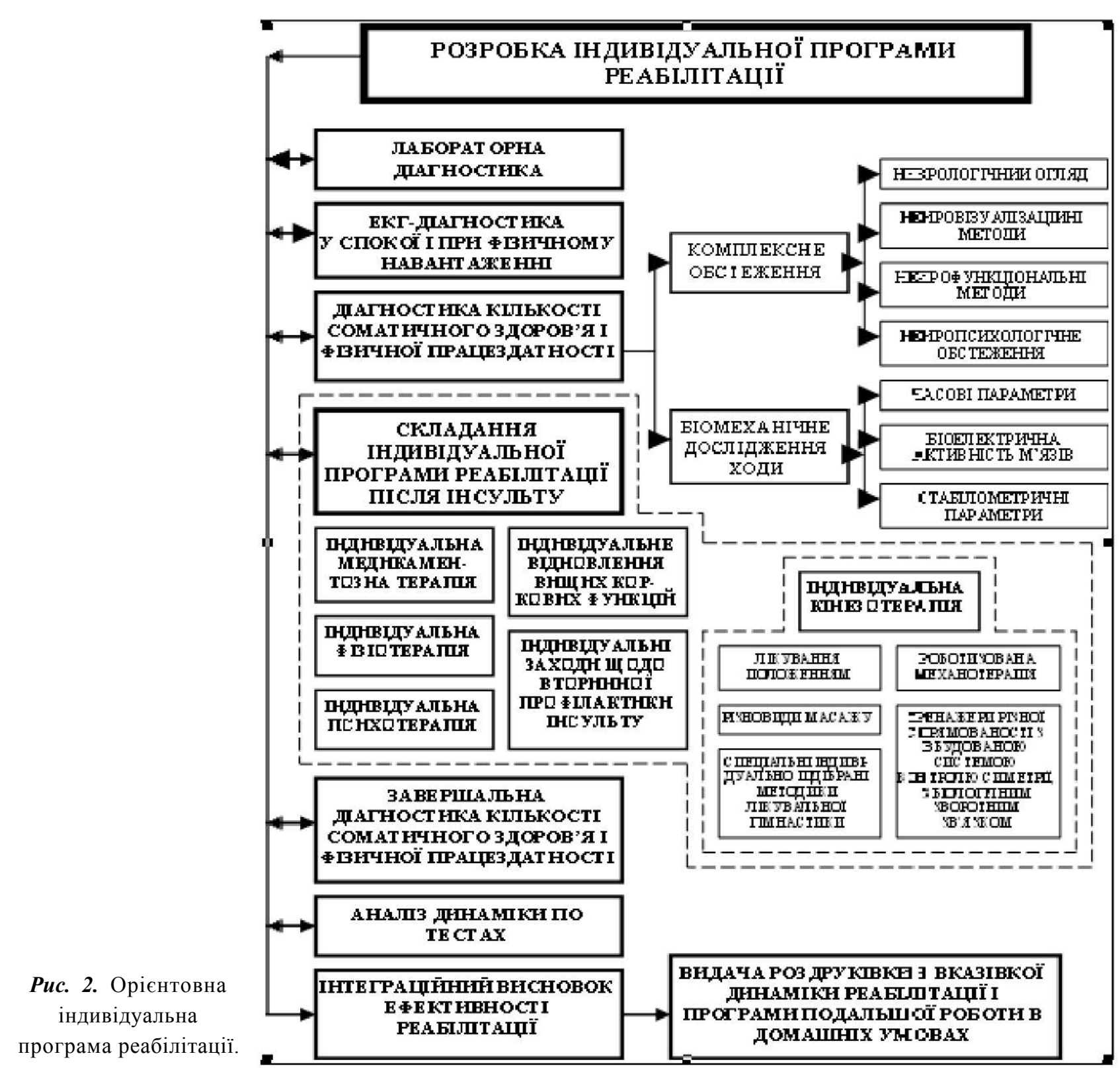

Іще однією $з$ особливостей запропонованої індивідуальної картки пацієнта є те, що вона логічно закінчується орієнтовним форматом індивідуальної програми реабілітації (розділ 8 картки, див. рис. 2), який можна вважати своєрідною підказкою, особливо для молодих лікарів, при визначенні по-

\section{Література}

1. Kwak Y. S. Health Informatics Activity : ISO/TC 215 / Y S. Kwak. - Daegu : Kyungpook Nat'l Univ Sch Med, 2004. $40 \mathrm{p}$.

2. Рот Г. 3. Медицинские информационные системы / Г. З. Рот, М. И. Фихман, Е. И. Шульман. - Новосибирск : дальшої тактики лікування і реабілітації постінсультних хворих.

Висновки. Розроблена індивідуальна картка пацієнта, максимально орієнтована на діагностику, дослідження, супровід і реабілітацію хворих, що перенесли мозковий інсульт.

НГТУ 2005. - $70 \mathrm{c}$.

3. Олійник I. В. Стан та перспективи вирішення проблеми мозкових інсультів, їх соціально-медичних наслідків (огляд літератури) / І. В. Олійник // Вісник морфології. - 2010. № 16 (3). - С. 734-738. 